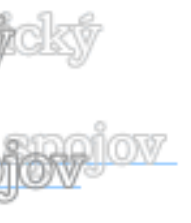

\title{
UMELÁ INTELIGENCIA, STROJOVÉ UČENIE A TRH PRÁCE
}

\author{
Katarína Štalmachová ${ }^{1}$, Mariana Strenitzerová ${ }^{2}$
}

\begin{abstract}
Machine learning is becoming a key problem-solving in finance, industry or energy sectors. Human resource management is no exception; machine learning in this area allows progress to be made in streamlining functions. The aim of the article is to evaluate the possibilities of using machine learning in human resource management and the impacts of artificial intelligence on the labour market.
\end{abstract}

Keywords: human resource management, machine learning, artificial intelligence

\section{Úvod}

Umelá inteligencia je rozvíjajúca sa oblast' technológie, kedy je počítačový systém naprogramovaný tak, aby dosiahol stanovený ciel' na základe súboru algoritmov alebo počítačových vzorcov [1]. Je možné konštatovat', že umelá inteligencia je v dnešnej dobe vel'kým trendom [2]. Marr chápe umelú inteligenciu ako zmenu v podnikaní, ktorá umožňuje l'ud'om pracovat' inteligentnejšie a rýchlejšie ako kedykol'vek predtým a môže mat' významný dopad na ekonomiku a aj samotný trh práce. Vo všeobecnosti možno umelú inteligenciu charakterizovat' ako technológiu, ktorá umožňuje strojom učit' sa bez l'udského zásahu iba s poskytnutím údajov [3]. Strojové učenie je podoblast' umelej inteligencie, zaoberajúca sa metódami a algoritmami, ktoré umožňujú programu učit' sa a následne adekvátne reagovat' na rôzne vstupné hodnoty bez toho, aby bol na ne explicitne naprogramovaný, len na základe informácií, ktoré sa naučil [4]. Samotná technológia strojového učenia nie je nová, ale v oblasti riadenia l'udských zdrojov sa začala presadzovat' až nedávno a v súčasnosti jej význam neustále rastie. V riadení l'udských zdrojov sa strojové učenie využíva pri plánovaní HR funkcií, využíva sa tiež pri analýze a spracovaní relevantných informácií, zefektívnení pracovných postupov, zlepšení postupov prijímania zamestnancov, znižovaní fluktuácie zamestnancov a školeniach, je možné ho využit' tiež pri meraní a riadení zapojenia zamestnancov a zlepšení programov odmien a uznania - motivačných programov.

$\mathrm{Na}$ druhej strane, s implementáciou umelej inteligencie môže dôjst' aj k obrovskému úbytku pracovných miest. Táto téma je vodbornej verejnosti vel'mi diskutovaná, avšak väčšina $\mathrm{z}$ nich predpovedá masívny posun $\mathrm{v}$ ekonomike a pracovných miestach. Pracovné miesta s nízkou kvalifikáciou alebo pracovné miesta, ktoré si vyžadujú opakujúce sa úlohy, sa nahradia strojmi [1].

\footnotetext{
${ }^{1}$ Ing. Katarína Štalmachová, Katedra spojov, FPEDAS, Žillinská univerzita v Žiline

e-mail: katarina.stalmachova@fpedas.uniza.sk

${ }^{2}$ doc. Ing. Mariana Strenitzerová, PhD., Katedra spojov, FPEDAS, Žillinská univerzita v Žiline

e-mail: mariana.strenitzerova@fpedas.uniza.sk
} 


\section{Strojové učenie}

Strojové učenie je technika analýzy údajov, ktorá učí počítače robit' to, čo je pre l'udí prirodzené, teda učit' sa zo skúseností. Algoritmy strojového učenia použivajú výpočtové metódy na získanie informácií priamo z údajov bez toho, aby sa ako model spoliehali na vopred určenú rovnicu. Algoritmy adaptívne zlepšujú svoj výkon so zvyšujúcim sa počtom vzoriek dostupných na učenie. Algoritmy strojového učenia nachádzajú v dátach prirodzené vzorce, ktoré generujú prehl'ad a pomáhajú zlepšovat' rozhodnutia a predikcie. Strojové učenie využíva dva typy techník: strojové učenie s učitel'om a strojové učenie bez učitel'a.

V rámci strojového učenia s učitel'om model aplikuje tzv. učenie sa od vzorov v minulých štruktúrovaných a pološtruktúrovaných dátach k novým údajom, na účely predikcie budúcich udalostí. Počiatočný súbor údajov sa používa na vytvorenie odvodenej funkcie, ktorá predpovedá výstupné hodnoty [5]. Strojové učenie s učitel'om (kontrolované učenie) vytvára model, ktorého výsledkom sú predpovede na základe dôkazov za prítomnosti neistoty. Algoritmus kontrolovaného učenia preberá známu množinu vstupných údajov a známe odpovede na výstupy a trénuje model na generovanie primeraných predpovedí. Tento typ strojového učenia je v praxi využívaný najčastejšie.

Učenie bez učitel’a nachádza v dátach skryté vzorce alebo vnútorné štruktúry. Strojové učenie bez učitel'a sa používa vtedy, ked' údaje nie je možné l'ahko klasifikovat'. V tomto prípade model analyzuje údaje a vyvodí závery popisujúce skryté štruktúry v množinách údajov [5]. Používa sa na vyvodenie záverov zo súborov údajov pozostávajúcich zo vstupných údajov bez označených odpovedí. Najpouživanejšou technikov učenia bez učitel'a je klastrovanie, ktoré sa používa na analýzu údajov pre zistenie skrytých vzorov alebo zoskupení v dátach. [5]. Na obrázku 1 sú zobrazené konkrétne techniky a metódy strojového učenia.

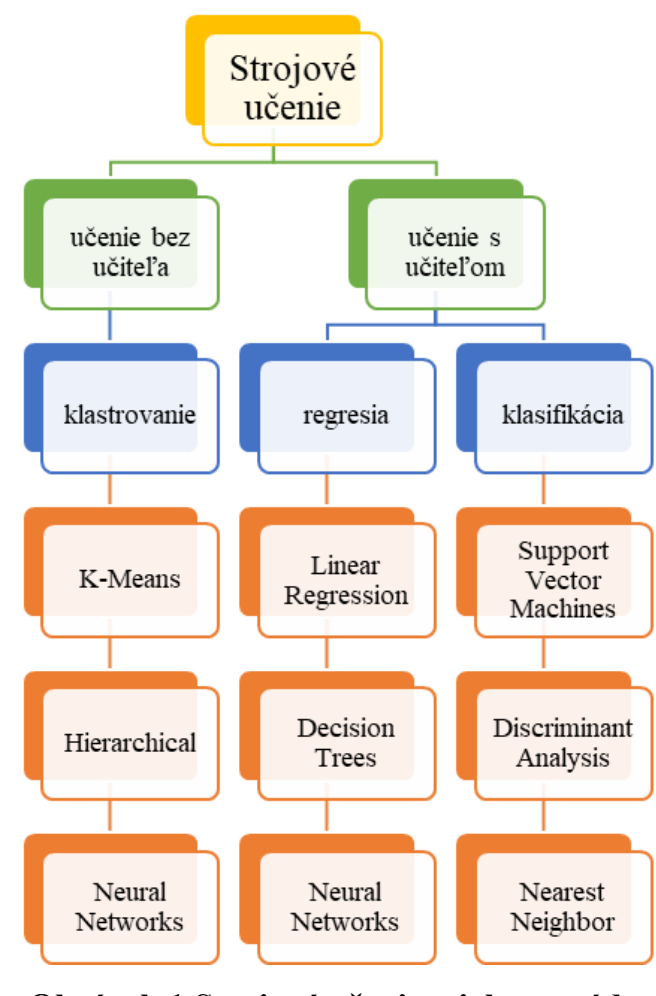

Obrázok 1 Strojové učenie a jeho metódy

Zdroj: vlastné spracovanie podl'a [5] [6] 


\section{Strojové učenie v riadení l'udských zdrojov}

Jednou z najdôležitejších úloh riadenia l'udských zdrojov a tiež jedným z najnáročnejších a najstrategickejších organizačných procesov je efektívne prijímanie vhodných pracovných síl. Podl'a štúdie Boston Consulting Group, náborová funkcia má najvýznamnejší vplyv na rast výnosov a ziskové marže spoločností v porovnaní s akoukol'vek inou funkciou v oblasti l'udských zdrojov [7]. Podl'a Sergotta až 74 \% zamestnávatel'ov prijalo do zamestnania na konkrétnu pozíciu nesprávneho človeka. Rizikom takéhoto nesprávneho výberu sú vynaložené náklady pre zamestnávatel'a, nízka výkonnost' zamestnancov, ale aj zvýšenie fluktuácie zamestnancov [8]. V tomto prípade môže využitie tejto metódy pomôct' organizáciám prijímat' lepšie rozhodnutia o prijímaní pracovníkov do zamestnania a zvýši efektívnost' riadenia pracovných síl. Významnú štúdiu v tejto oblasti zrealizovali Pessach a kol., ktorých ciel'om bolo vyvinút' nástroj na podporu rozhodovania pre personalistov v oblasti náboru a umiestňovania zamestnancov. Vstupné dáta pre strojové učenie získali na základe prieskumu zrealizovaného na vzorke 700000 respondentov (zamestnancov, ktorí boli zamestnaní v danej firme za 10 rokov). Klasifikačné algoritmy boli natrénované na $70 \%$ respondentov v súbore údajov. Následne v testovacej fáze predpovedali úspešnost' náboru zostávajúcich $30 \%$ kandidátov. Poukázali na to, že je možné predpovedat' úspešné umiestnenie kandidáta na konkrétnu pozíciu ešte v štádiu pred náborom a využit' predpovede na vytvorenie modelu globálnej optimalizácie. Výsledky ich práce tiež ukazujú, že navrhnutý model je schopný poskytnút' vyvážený náborový plán a zároveň zlepšit' rozmanitost' a úspešnost' náboru [9].

Predikcii fluktuácie zamestnancov sa venujú napríklad aj Zhao a kol., ktorí vo svojej práci opísali, demonštrovali a zhodnotili rôzne algoritmy strojového učenia s učitel'om z hl'adiska ich schopnosti predikovat' fluktuáciu zamestnancov [10]. Predikcii fluktuácie zamestnancov sa venujú aj Jhaver a kol. Ich výskum je zameraný na vývoj modelov, ktoré dokážu predpovedat' fluktuáciu zamestnancov a môžu pomôct' organizácii podniknút' potrebné kroky na udržanie týchto zamestnancov. Na základe ich výskumu došli k záveru, že zamestnanci, ktorí skončili pracovný pomer mali nižšiu úroveň spokojnosti. V práci implementovali rôzne klasifikačné modely ako napríklad Support Vector Machine, Random Forest Model, Gradient Boosting Classifier a Neural Networks. Zistili, že najpresnejším modelom na predikciu fluktuácie zamestnancov je Gradient Boosting Classifier s presnost'ou 98,5 \% a Random Forest s presnost'ou 97,4 \%. Príspevok sa zameriava nielen na predikciu fluktuácie zamestnanca, ale aj na odhad časového rozsahu a pravdepodobnosti odchodu [11].

V oblasti riadenia l'udských zdrojov je možné použit' strojové učenie aj na predikciu výkonu zamestnancov. Analýza výkonu zamestnancov vakejkol'vek organizácii je v súčasnosti nutnost'ou, pretože rôzni l'udia majú rôzne zručnosti a odlišné charakteristiky správania. Štúdiom využitia strojového učenia na predikciu výkonnosti zamestnancov sa zaoberali Lather a kol. Vo svojej štúdii sa zamerali na strojové učenie s učitel'om s využitím rôznych techník, ako napríklad Support Vector Machines, Random Forest, Naive Bayes, Neural Netowrks a Logistic Regression. V tomto prípade sa technika Support Vector Machines ukazuje ako najefektívnejšia na predikciu výkonnosti zamestnancov z hladiska jej presnosti [12]. 


\section{Umelá inteligencia a jej vplyv na trh práce}

Umelá inteligencia, robotika a d’alšie formy inteligentnej automatizácie napredujú rýchlym tempom a majú potenciál priniest' hospodárstvu vel'ké výhody prostredníctvom zvyšovania produktivity práce a vytvárania nových a lepších produktov a služieb. Môžu tiež spôsobit' výrazné zmeny na trhu práce, kde môže dôjst' až $\mathrm{k}$ strate pracovných miest najmä u nízkokvalifikovaných zamestnancov a zamestnancov v určitých odvetviach [13]. Vplyv umelej inteligencie na trh práce je možné rozlišovat' aj z hl'adiska pohlavia. Doprava vyniká ako odvetvie s obzvlášt' vysokým potenciálom automatizácie $\mathrm{z}$ dlhodobého hl'adiska, predpokladá sa, že je ohrozených až $50 \%$ pracovných miest $\mathrm{v}$ doprave. Vplyvom digitálnych technológií na trh práce v sektore dopravy sa zaoberali napríklad Chinoracký a Č́orejová, ktorí dospeli k záveru, že trh práce $\mathrm{v}$ tomto sektore sa môže zmenit' a táto zmena závisí od úrovne zručností potrebných pre jednotlivé pracovné miesta. Dramatická zmena môže nastat' aj v poklese pracovných miest vyžadujúcich menej kvalifikovanú pracovnú silu [14]. Rovnako aj pracovné miesta vo finančnej oblasti môžu byt' ovplyvnené automatizáciou; tie sú citlivé na automatizáciu skôr z krátkodobého hl’adiska.

Podl'a Chinorackého a Čorejovej sa v globálnom meradle podiel pracovných miest, ktorým hrozí riziko automatizácie, v jednotlivých krajinách líši. Severná Európa, Severná Amerika a Nový Zéland sú vo všeobecnosti menej náchylné na riziko automatizácie pracovných miest. Krajiny východnej a južnej Európy čelia ovel'a väčšiemu riziku automatizácie pracovných miest. Na základe ich výpočtov majú krajiny s vysokou mierou nezamestnanosti vyššie riziko automatizácie pracovných miest. Na druhej strane uvádzajú, že čím nižšia je nezamestnanost', tým klesá úroveň rizika automatizácie pracovných miest. $\mathrm{Na}$ základe uvedeného je preto potrebné, aby sa krajiny pripravili na potenciálne riziká spojené s vplyvom automatizácie na trh práce [14].

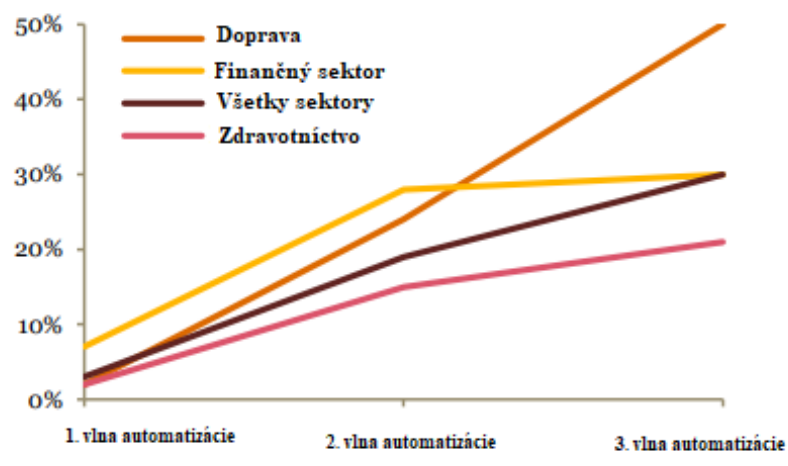

Obrázok 2 Riziko automatizácie podl’a oblastí

Zdroj: vlastné spracovanie podl'a [13]

Podla štúdie PWC sa predpokladá, že v 3. vlne automatizácie (30. roky 21. storočia) budú najviac zasiahnutí zamestnanci s nízkou kvalifikáciou, teda riziko automatizácie na pracovných miestach, ktoré vyžadujú nízku kvalifikáciu je takmer $50 \%$. To odráža väčšiu prispôsobivost' vysoko vzdelaných pracovníkov technologickým zmenám a skutočnost', že je pravdepodobnejšie, že budú vo vyšších manažérskych rolách, ktoré budú stále potrebné aj pre uplatnenie l'udského úsudku, pokial' ide o navrhovanie a dohl'ad nad systémami založenými na umelej inteligencii. Z tohto pohl'adu je už v súčasnosti dôležité venovat' zvýšenú pozornost' investíciám do celoživotného vzdelávania a rekvalifikácie. 


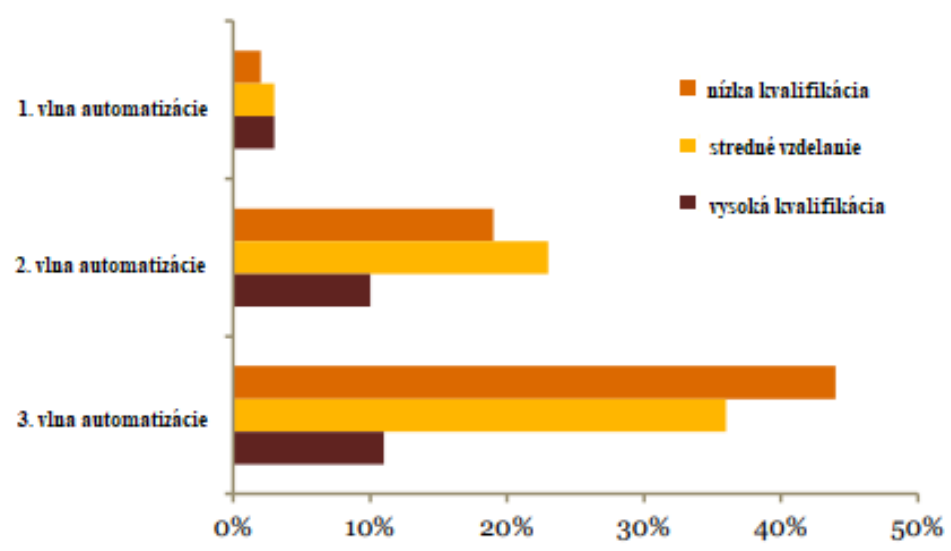

Obrázok 3 Riziko automatizácie podl’a vzdelania

Zdroj: vlastné spracovanie podl'a [13]

Predpokladá sa, že ženy budú v nasledujúcom desat'ročí viac zasiahnuté automatizáciou, mužské povolania však môžu byt' z dlhodobého hl'adiska viac ohrozené.

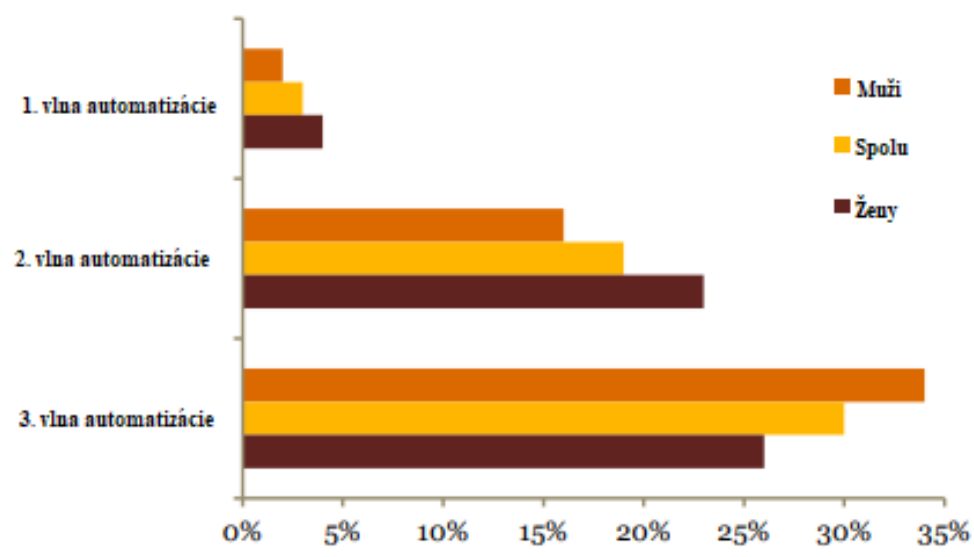

Obrázok 4 Riziko automatizácie podl’a pohlavia

Zdroj: vlastné spracovanie podl'a [13]

Odhadovaný podiel pracovných miest s vysokým rizikom automatizácie sa v jednotlivých krajinách líši. Slovenská republika patrí medzi krajiny s vysokým podielom pracovných miest ohrozených automatizáciou, v 30. rokoch môže tento podiel dosiahnut' takmer $45 \%$, a tým sa Slovenská republika umiestnila na 1. mieste v rebríčku krajín. Túto skutočnost' potvrdila aj štúdia OECD, ktorá rovnako zaradila Slovensko na 1. miesto z pohl'adu vysokého rizika dopadu automatizácie na trh práce [15]. 


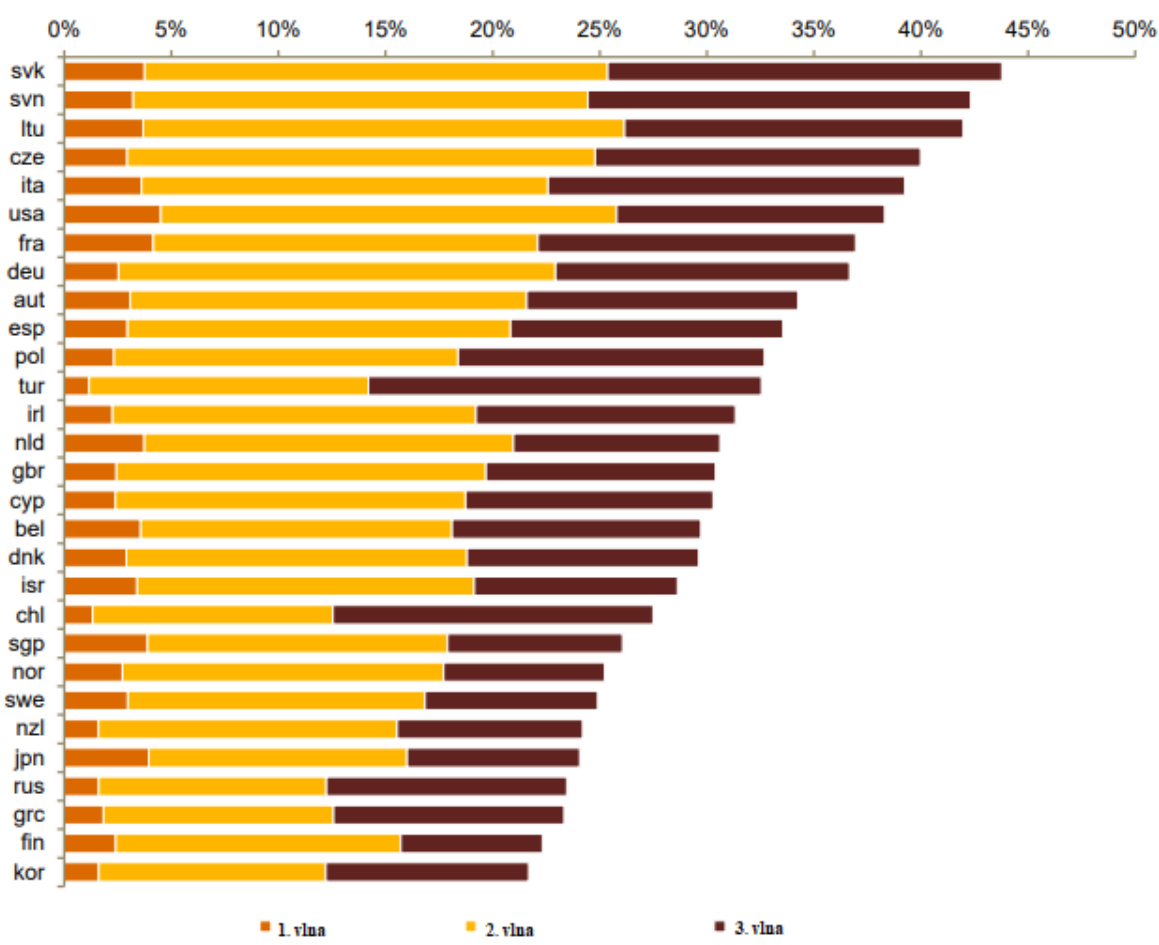

Obrázok 5 Riziko automatizácie podl’a krajín

Zdroj: vlastné spracovanie podl'a [13]

\section{Záver}

Je možné konštatovat', že trh práce v Slovenskej republike čakajú v blízkej budúcnosti výrazné zmeny, a to najmä $v$ súvislosti $\mathrm{s}$ automatizáciou a implementáciou umelej inteligencie. $\mathrm{Z}$ pohl’adu trhu práce budú výrazne ohrození nízkokvalifikovaní zamestnanci a z dlhodobého hl'adiska najmä ženy. Či už zamestnanci stratia prácu $\mathrm{v}$ dôsledku automatizácie, alebo sa musia prispôsobit' novým úlohám a obsahu práce, systémy celoživotného vzdelávania sú výzvou. Podl'a štúdie OECD, v súčasnosti sa približne $40 \%$ pracovníkov zúčastňuje na odbornej príprave týkajúcej sa zamestnania, ale účast' často predstavuje iba niekol'ko hodín ročne [15]. Požiadavky na vedomosti sa budú vo väčšine profesií rýchlo menit', nová digitálna ekonomika si bude vyžadovat' vel'a technických znalostí, ktoré bude potrebné doplńnat' počas celého pracovného života. Preto sa bude musiet' zmenit' aj systém prípravy a odborného vzdelávania súčasných aj budúcich pracovníkov [16]. Je dôležité uvedomit' si, že budúcnost' spočíva v inováciách, a to si vyžaduje neustále zlepšovanie na trhu práce.

\section{Literatúra}

[1] Thacker, J. (2018). The future is here: Artificial Intelligence and the changing workforce [online]. Dostupné na: https://erlc.com/resource-library/articles/the-future-is-hereartificial-intelligence-and-the-changing-workforce/

[2] Carter, R. (2017). The growing power of artificial intelligence in workplace collaboration. [online]. Dostupné na: https://www.uctoday.com/collaboration/growingpower-artificial-intelligence-workplace-collaboration/ 
[3] Marr, B. (2018). The economics of artificial intelligence - How cheaper predictions will change the world [online].Dostupné na: https://www.forbes.com/sites/bernardmarr/2018/07/10/the-economics-of-artificialintelligence-how-cheaper-predictions-will-change-the-world/\#7b78149d5a0d

[4] Cibula, M. (2017). Definícia [online]. Dostupné na: https://smnd.sk/mcibula/zakl_info/definicia.html

[5] Mohr, T. (2019). In the loop - chapter 26: AI, Machine learning and deep learning [online]. Dostupné na: https://medium.com/ceoquest/in-the-loop-chapter-26-ai-machinelearning-and-deep-learning-140cc13a77b7

[6] Mathworks: What is machine learning? [online]. Dostupné na: https://ch.mathworks.com/discovery/machine-learning.html

[7] Sullivan, J. (2012). News flash: Recruiting has the highest business impact of any HR function [online]. Dostupné na: https://www.ere.net/news-flash-recruiting-has-thehighest-business-impact-of-any-hr-function/

[8] Sergott, T. (2018). Artificial intelligence and its impact on contingent workforce management [online]. Dostupné na: https://www.forbes.com/sites/forbestechcouncil/2018/04/17/artificial-intelligence-and-itsimpact-on-contingent-workforce-management/\#3878487771b2

[9] Pessach, D., Singer, G., Avrahami, D., Hila et al. (2020). Employees recruitment: A prescriptive analytics approach via machinelearning and mathematical programming. Decision Support Systems 134 (2020). doi.org/10.1016/j.dss.2020.113290

[10]Zhao, Y., Hryniewicki, M. K., Cheng, F., Fu, B., Zhu X. (2018). Employee Turnover Prediction with Machine Learning: A Reliable Approach. doi.org/10.1007/978-3-03001057-7 56

[11]Jhaver, M., Gupta, Y., Mishra, A. K. (2019). Employee turnover prediction system. International conference on imformation systems and computer networks 2019.

[12]Lather, A. S., Malhotra, R., Saloni, P., Singh, P., Mittal, S. (2019). Prediction of employee performance using machine learning techniques. doi.org/10.1145/3373477.3373696

[13]PWC (2018). Will robots really steal our jobs? [online]. Dostupné na: https://www.pwc.com/hu/hu/kiadvanyok/assets/pdf/impact of automation on jobs.pdf

[14] Chinoracky, R., Corejova, T. (2019). Impact of Digital Technologies on Labor Market and the Transport Sector. 13th International Scientific Conference on Sustainable, Modern and Safe Transport (TRANSCOM 2019). DOI: $10.1016 / \mathrm{j} . t r p r o .2019 .07 .139$

[15] OECD (2018). Putting faces to the jobs at risk of automation [online]. Dostupné na: http://www.oecd.org/employment/Automation-policy-brief-2018.pdf

[16] Pikus, M., Hrabovský, R. Umelá inteligencia na Slovensku: využitie, dosah na trh práce a etické aspekty [online]. Dostupné na: https://www.exe.sk/sites/default/files/202006/umela-inteligencia-na-Slovensku-e-book.pdf

\section{Grantová podpora}

VEGA 1/0152/18 Obchodné a podnikatel'ské modely a platformy v digitálnom prostredí. 